1996

\title{
The Young Parsons and the Mature Habermas
}

James J. Chriss

Cleveland State University

Follow this and additional works at: https://engagedscholarship.csuohio.edu/clsoc_crim_facpub

Part of the Criminology Commons

How does access to this work benefit you? Let us know!

\section{Repository Citation}

Chriss, James J., "The Young Parsons and the Mature Habermas" (1996). Sociology \& Criminology

Faculty Publications. 93.

https://engagedscholarship.csuohio.edu/clsoc_crim_facpub/93

This Article is brought to you for free and open access by the Sociology \& Criminology Department at EngagedScholarship@CSU. It has been accepted for inclusion in Sociology \& Criminology Faculty Publications by an authorized administrator of EngagedScholarship@CSU. For more information, please contact library.es@csuohio.edu. 


\title{
The Young Parsons and the Mature Habermas
}

\author{
James J. Chriss
}

Throughout his career Parsons steadfastly clung to a multiperspectival approach that attempted to avoid the one-sided dogmatism of those systems of thought that happened to be in ascendancy during any particular disciplinary epoch. ${ }^{58}$ During his Amherst days and beyond, Parsons was confronted with the ideas of unitary evolution, empiricism, positivism, organicism, and neoclassical economics, as well as the equally one-side reaction to the latter, namely unorthodox institutional economics. 59

This approach to social explanation was certainly evident in Parsons's Amherst papers. In his "Theory of Human Behavior in its Individual and Social Aspects," Parsons stressed that prevailing mechanistic and behavioristic systems of thought may not be appropriate for ethics and human behavior in light of cumulated knowledge ("facts"). Parsons is careful not to let the idea of the importance of "habit forming influences" on individual behavior lead him to embrace uncritically the organicism that was still prevalent during his time. Later Parsons got into an expanded discussion of culture, and especially the importance of cultural diffusion and convergence, to explain change and evolution of social systems (p. 15) Parsons's goal here is to emphasize that explanations of human society must move beyond unilinear models, whether based on individual habit (e.g., utilitarianism or behaviorism) at one extreme, or the power of institutions or culture over the individual (e.g., institutional economics) at the other.

On page 23 Parsons stated that “... there is no reason to make any radical distinction in kind between habits of thought and technological habits. We are one organism, not two, and viewed from one angle we are physical, from another mental, from another moral." This is extremely important; Parsons was attempting to overcome the overly simplistic idea that there are two social realities, namely the individual and society (the now famous and still unresolved "micro-macro" debate).

It is noteworthy also that the entire basis of Habermas's $(1984,1987)$ theory

Address for correspondence: James J. Chriss, Kansas Newman College, Sociology Department, 3100 McCormick Ave., Wichita, KS, 67213; e-mail: chrissj@ksnewman.edu 
of communicative action banks on the distinctions Parsons made some sixty years previously, namely Habermas's notion of the universal validity claims underlying all speech (or speech acts). The three dimensions (or analytical worlds) corresponding to the three validity claims are the subjective world (the validity claim of subjective truthfulness), the objective world (the validity claim of propositional truth), and the social world (the validity claim of normative rightness). Of course, this makes sense only in postconventional (modern) societies, because prior to that time, persons often drew upon only one world in making claims (such as appealing to tradition, the divine right of kings, aesthetics, religion, or whatever).

Habermas's penchant for grand, overarching theory was borrowed from Parsons, and Parsons himself had been earlier influenced by that unique German brand of theorizing tracing back through Hegel and Marx, Simmel, Weber and Mannheim. ${ }^{60}$ In effect, the same logic underlying Habermas's analytic of the three worlds and the three validity claims can be found in the pages of Parsons's Amherst papers. Wearne $(1989$, p. 31$)$ suggests that, influenced by the holism of German Enlightenment thought, Parsons was led to conceive of the unity of social explanation as hinging on the merging of three basic modal aspects of the human organism-the physico-chemical, the psychological-mental, and the social-moral-aspects which had been driven apart or treated separately in utilitarian, behavioristic, or even institutionalist systems of thought (see also Camic 1991).

In these postmodern times, where many observers are theorizing the end of the subject, a loss of certitude in the veracity of our modern social institutions (e.g., law, the family, science, the media), and especially an end to the grand "metanarrative" of Enlightenment rationality (e.g., Lyotard 1984), Jurgen Habermas stands almost as a lone voice in defense of the type of modernist social theorizing that Parsons championed. Habermas (1987) states for example that "no theory of society can be taken seriously today if it does not at least situate itself with respect to Parsons" (p. 199). But also in good Parsonian fashion, Habermas has never been wholly enamored of Parsons's ideas (see, e.g., Chriss 1995). In other words, just as Parsons established in his Amherst papers and beyond, Habermas approaches prevailing systems of thought critically, with an eye toward improving upon those ideas (including Parsons's own) and incorporating what is useful from them into his own evolving theoretical schema. ${ }^{61}$

These undergraduate Amherst papers attest to the vision and importance of Parsons's approach to social explanation. They also serve to mark a clear lineage or continuity between the early stages of German enlightenment theorizing-of which Parsons was an heir-and current efforts to fashion an improved theory of society, the latter represented especially by Habermas's theory of communicative action.

\section{References}

Bershady, Harold J. 1973. Ideology and Soctal Knowledge. New York: Wiley.

Bershady, Harold J. 1991. Practice against Theory in American Sociology: An Exercise in the Sociology of 
Knowledge. Pp. 66-84 in Talcott Parsons: Theorist of Modernity, edited by R. Robertson and B.S. Turner. London: Sage.

Camic, Charles. 1991. Introduction: Talcott Parsons before The Structure of Soctal Action. Pp. ix-lxix in Talcott Parsons: The Early Essays, edited by C. Camic. Chicago: University of Chicago Press.

Chriss, James J. 1995. Habermas, Goffman, and Communicative Action: Implications for Professional Practice. American Sociological Review 60:545-565.

Habermas, Jurgen. 1984. The Theory of Communicative Action, volume one, translated by T. McCarthy. Boston: Beacon Press.

Habermas, Jurgen. 1987. The Theory of Communicative Action, volume two, translated by T. McCarthy. Boston: Beacon Press.

Lyotard, Jean-Francois. 1984. The Postmodern Condition. Minneapolis: University of Minnesota Press.

Simich, J.L. and Rick Tilman. 1983. On the Use and Abuse of Thorstein Veblen in Modern American Sociology, I; David Riesman's Reductionist Interpretation and Talcott Parsons' Pluralist Critique. Amertcan Journal of Economics and Soctology 42 (4):417-429.

Wearne, Bruce C. 1989. The Theory and Scbolarship of Talcott Parsons to 1951. Cambridge: Cambridge University Press. 